\title{
ANALISIS IMPLEMENTASI KEBIJAKAN PENGENDALIAN PEMBUANGAN LIMBAH CAIR DOMESTIK KE BADAN AIR PENERIMA DI KABUPATEN PURWAKARTA
}

\author{
Futiha Nazar $^{1 * *}$, Sutarto Mochtar ${ }^{2)}$, Ely Sufianti ${ }^{3)}$, Endang Wirjatmitrilestari ${ }^{4)}$, Edah Jubaedah ${ }^{5}$ \\ ${ }^{1}$ Administrasi Pembangunan Negara, Politeknik Sekolah Tinggi Ilmu Administrasi Lembaga \\ Administrasi Negara (STIA LAN) Bandung, Bandung, Jawa Barat, Indonesia \\ futhy_nz@yahoo.co.id
}

${ }^{2}$ Administrasi Pembangunan Negara, Politeknik Sekolah Tinggi Ilmu Administrasi Lembaga Administrasi Negara (STIA LAN) Bandung, Bandung, Jawa Barat, Indonesia tartomochtar19@gmail.com

${ }^{3}$ Administrasi Pembangunan Negara, Politeknik Sekolah Tinggi Ilmu Administrasi Lembaga Administrasi Negara (STIA LAN) Bandung, Bandung, Jawa Barat, Indonesia sufiantiely@gmail.com

${ }^{4}$ Administrasi Pembangunan Negara, Politeknik Sekolah Tinggi Ilmu Administrasi Lembaga Administrasi Negara (STIA LAN) Bandung, Bandung, Jawa Barat, Indonesia e.wirjatmi01@gmail.com

${ }^{5}$ Administrasi Pembangunan Negara, Politeknik Sekolah Tinggi Illmu Administrasi Lembaga Administrasi Negara (STIA LAN) Bandung, Bandung, Jawa Barat, Indonesia e_jubaedah@yahoo.com
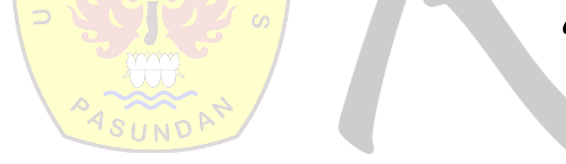

\section{ABSTRAK}

\begin{abstract}
Implementasi kebijakan pengendalian pembuangan limbah cair domestik di Kabupaten Purwakarta belum terlaksana karena belum ada pengaturan terkait pengelolaannya. Sejauh ini air limbah domestik langsung dibuang ke saluran drainase/sungai karena belum tersedianya sarana dan prasarana pengelolaan air limbah domestik, kurangnya pemahaman masyarakat terhadap dampak air limbah domestik terhadap pencemaran air. Di samping itu belum adanya aturan tingkat operasional terkait implementasi kebijakan pengelolaan air limbah domestik. Metode yang digunakan pendekatan kualitatif dengan informasi dari pelaksana kebijakan pada Dinas Lingkungan Hidup dan kelurahan terkait. Analisis implementasi kebijakan menggunakan pendekatan George C. Edward III yang meliputi komunikasi,sumberdaya, disposisi dan struktur birokrasi. Hasil penelitian menunjukkan bahwa untuk mengatasi permasalahan implementasi kebijakan pengendalian pembuangan limbah cair domestik, Pemerintah Kabupaten Purwakarta perlu melaksanakan beberapa tindakan dalam pengendalian pencemaran pembuangan limbah cair domestik ke badan air penerima. Adapun Langkah-langkah yang dapat dilakukan adalah mengoptimalkan kinerja sumberdaya manusia yang terbatas, penyediaan anggaran, dan kerjasama antara pihak pemerintah, swasta dan masyarakat. Implementasi kebijakan akan terlaksana apabila Kabupaten Purwakarta telah mempunyai acuan diantaranya data inventarisasi dan identifikasi sumber pencemar limbah cair domestik, Standard Operational Procedure (SOP) Pengendalian Pembuangan Limbah Cair Domestik, dan peraturan bupati tentang pengelolaan limbah cair domestik.
\end{abstract}

Kata Kunci: Kebijakan Publik, Implementasi Kebijakan, Limbah Cair Domestik 


\title{
Kebijakan: Jurnal Ilmu Administrasi \\ Volume 12, Nomor 1, Januari 2021 \\ E-ISSN: 2656-2820 \\ P-ISSN 1829-5762
}

\begin{abstract}
The implementation of the domestic liquid waste disposal control policy in Purwakarta Regency has not been implemented because there are no regulations regarding its management. So far, domestic wastewater is discharged directly into drainage channels / rivers due to the unavailability of facilities and infrastructure for domestic wastewater management, lack of public understanding of the impact of domestic wastewater on water pollution. In addition, there are no operational level regulations regarding the implementation of domestic wastewater management policies. The method used is a qualitative approach with information from policy implementers at the Environmental Agency and related sub-district. Analysis of policy implementation uses the George C. Edward III approach which includes communication, resources, dispositions and bureaucratic structures. The results showed that in order to solve the problem of implementing the domestic liquid waste disposal control policy, the Purwakarta Regency Government needs to carry out several actions in controlling domestic liquid waste disposal pollution to receiving water bodies. The steps that can be taken are optimizing the performance of limited human resources, provision of a budget, and cooperation between the government, the private sector and the community. Policy implementation can be carried out if Purwakarta Regency already has references including inventory data and identification of sources of domestic liquid waste pollutants, Standard Operational Procedure (SOP) for Domestic Wastewater Disposal Control, and regent regulations on domestic liquid waste management.
\end{abstract}

Keywords: Public Policy, Policy Implementation, Domestic Liquid Waste

\section{PENDAHULUAN}

Masalah pencemaran air sungai akhir-akhir ini menjadi perhatian pemerintah pusat terkait terjadinya pencemaran air sungai Citarum. Air dan lingkungan sekitarnya telah tercemar selama puluhan tahun. Walaupun telah terjadi pergantian generasi dan perubahan kepemerintahan, pada kenyataannya kualitas air Sungai Citarum belum mengalami peningkatan (Teguh, 2019). Beberapa sungai yang mengalir di Kabupaten Purwakarta merupakan anak Sungai Citarum yaitu Sungai Cikao, Sungai Cikembang, Sungai Cikuda, Sungai Cigalugur dan Sungai Cimunjul. Kelima anak sungai tersebut apabila tidak dikelola dengan baik akan mejadi penyumbang pencemaran terhadap Sungai Citarum. Hal ini tentunya akan menambah beban pencemaran di Sungai Citarum sehingga upaya pemulihan kondisi air Sungai Citarum tidak akan terwujud.

Permasalahan penurunan kualitas air sungai ini jika tidak dikelola dengan baik akan menyebabkan pencemaran air sungai. Pada akhirnya akan berpengaruh terhadap pembudidayaan ikan, hewan, tanaman, kualitas tanah dan air tanah yang pada akhirnya akan berpengaruh terhadap kesehatan masyarakat. Untuk itu perlu dilakukan pengawasan terhadap kegiatan pembuangan air limbah ke sungai. Selain itu perlu terus dilakukan pembinaan dan pemantauan kualitas air sungai untuk mengetahui kualitas air sungai yang mengalir di Kabupaten Purwakarta. Penelitian dilakukan terhadap 5 anak Sungai Citarum yang ada di Kabupaten Purwakarta dengan hasil sebagai berikut:

1. Pada tahun 2014 sekitar $\pm 90 \%$ sungai termasuk dalam kategori cemar sedang dan $\pm 10 \%$ termasuk dalam kategori cemar ringan.

2. Pada tahun 2015 sekitar $\pm 45 \%$ sungai termasuk dalam kategori cemar sedang dan $\pm 55 \%$ termasuk dalam kategori cemar ringan.

3. Pada tahun 2016 sekitar $\pm 35 \%$ sungai termasuk dalam kategori cemar sedang dan $\pm 65 \%$ termasuk dalam kategori cemar ringan.

4. Pada tahun 2017 sekitar $\pm 50 \%$ sungai termasuk dalam kategori cemar sedang dan $\pm 40 \%$ termasuk dalam kategori cemar ringan serta $\pm 10 \%$ sungai termasuk dalam kategori memenuhi baku mutu. (Sumber: Dinas Lingkungan Hidup, 2018).

Berdasarkan data tersebut, kondisi air sungai di Purwakarta mengalami pencemaran dengan kategori cemar ringan sampai sedang. Hal ini menunjukkan bahwa masih perlu upaya peningkatan 
pengendalian pembuangan air limbah ke sumber air dengan memperhatikan semua faktor yang mempenggaruhi pencemaran air sungai. Berdasarkan hasil penelitian diketahui bahwa limbah domestik dan limbah peternakan merupakan kontribusi terbesar dalam pencemaran air sungai Citarum di Kabupaten Purwakarta. Sedangkan bakumutu parameter BOD (Biologycal Oxigen Demand) yang boleh dibuang ke badan air penerima/sungai adalah $30 \mathrm{mg} / \mathrm{L}$.

Tabel 1. Kontribusi Sumber Pencemar Biologycal Oxigen Demand (BOD) di Kabupaten Purwakarta

\begin{tabular}{|c|c|c|c|c|c|}
\hline $\begin{array}{c}\text { Domestik } \\
(\mathbf{K g} / \mathbf{h r})\end{array}$ & $\begin{array}{c}\text { Peternakan } \\
(\mathbf{K g} / \mathbf{h r})\end{array}$ & $\begin{array}{c}\text { Industri } \\
(\mathbf{K g} / \mathbf{h r})\end{array}$ & $\begin{array}{c}\text { Perianan } \\
(\mathbf{K g} / \mathbf{h r})\end{array}$ & $\begin{array}{c}\text { Non Point Source } \\
(\mathbf{N P S})(\mathbf{K g} / \mathbf{h r})\end{array}$ & $\begin{array}{c}\text { Total } \\
(\mathbf{K g} / \mathbf{h r})\end{array}$ \\
\hline $12.011,80$ & $14.875,14$ & $5.972,27$ & $6.907,01$ & $2.141,90$ & $41.908,11$ \\
\hline
\end{tabular}

Sumber: Kajian DTBPS Citarum, KLHK 2017.

Hal ini memberikan gambaran bahwa implementasi kebijakan pengendalian pembuangan limbah cair domestik ke badan air penerima di Kabupaten Purwakarta belum terlaksana dengan baik. Apabila tidak dilakukan pengelolaan terhadap limbah cair domestik ini, maka kondisi air sungai di Kabupaten Purwakarta akan semakin memburuk. Untuk itu perlu dirumuskan kebijakan tentang pengendalian pembuangan limbah cair domestik. Melalui implementasi kebijakan diharapkan pengelolaan air limbah domestik dapat dilaksanakan sehingga kualitas air sungai dapat dikendalikan bahkan tidak tercemar. Berdasarkan uraian yang telah dipaparkan pada latar belakang, maka dapat ditentukan rumusan masalahnya berupa pertanyaan penelitian sebagai berikut: Bagaimana implementasi kebijakan pengendalian pembuangan limbah cair domestik ke badan air penerima di Kabupaten Purwakarta? Adapun manfaat dari penelitian ini diharapkan akan memberikan konsep pengembangan studi ilmu administrasi pembangunan negara, khususnya kebijakan publik terkait implementasi kebijakan. Kebijakan publik memiliki banyak makna pengertian sesuai dengan pandangan masing-masing ahli. Menurut Thomas Dye (1981) dalam Subarsono (2011:2) mengemukakan bahwa kebijakan publik merupakan apapun pilihan pemerintah untuk melakukan atau tidak (public policy is whatever government choose to do or not to do).

Nugroho (2008:55) merumuskan definisi kebijakan publik yaitu: "Kebijakan publik adalah keputusan yang dibuat oleh negara, dalam hal ini yaitu oleh pemerintah, yang digunakan sebagai strategi untuk merealisasikan apa yang menjadi tujuan negara. Kebijakan publik juga merupakan strategi yang digunakan untuk mengantarkan masyarakat pada masa perubahan menuju masyarakat yang dicitacitakan". Berdasarkan pendapat dan konsep yang telah dikemukakan oleh para ahli, kebijakan publik merupakan tindakan yang diambil oleh pemerintah dalam suatu kondisi untuk menindaklanjuti permasalahan publik yang mungkin akan terjadi atau sudah terjadi dan mengabdi pada kepentingan masyarakat. Tindakan yang telah dipilih, dipengaruhi oleh beberapa hal seperti lingkungan, sumberdaya dan hal lainnya. Implementasi kebijakan sangat penting untuk merealisasikan tujuan yang telah ditetapkan dalam suatu kebijakan. Winarno (2016:134) menjelaskan makna implementasi kebijakan merupakan tahap dari proses kebijakan segera setelah penetapan undang-undang, jika dipandang dalam pengertian yang luas. Agustino (2017:129) juga mengemukakan bahwa implementasi merupakan suatu proses yang dinamis, dimana suatu aktivitas atau kegiatan yang dilakukan pelaksana kebijakan akan mendapatkan hasil yang sesuai dengan tujuan atau sasaran kebijakan tersebut. Implementasi suatu kebijakan pemerintah merupakan suatu bentuk pelayanan yang diberikan kepada masyarakat, sesuai dengan fungsi dari birokrasi pemerintah untuk melayani masyarakat. Menurut Subarsono (2015:87) mengungkapkan bawha kebijakan yang telah direkomendasikan oleh pemerintah tidak akan menjadi jaminan bahwa kebijakan tersebut akan berhasil dalam implementasinya. 


\section{Kebijakan: Jurnal Ilmu Administrasi \\ Volume 12, Nomor 1, Januari 2021 \\ E-ISSN: 2656-2820 \\ P-ISSN 1829-5762}

Selanjutnya keberhasilan implementasi menurut Edward III dalam Subarsono (2011:90-92) dipengaruhi oleh empat variabel, yaitu komunikasi, sumberdaya, disposisi, dan struktur birokrasi. Setidaknya George C. Edward III mengatakan bahwa dalam pendekatan studi implementasi kebijakan pertanyaan abstraknya diawali dari bagaimana prakondisi untuk suksesnya kebijakan publik dan apa hambatan utama dari kesuksesan kebijakan publik tersebut. Edward III (1980:10) mengemukakan empat faktor dalam mengimplementasikan kebijakan publik, yakni: Communication, Resourches, Dispotition or Attitudes, and bureaucratic Structure atau dengan kata lain yaitu komunikasi, sumberdaya, sikap pelaksana, dan struktur birokrasi. Pencemaran air sungai/perairan merupakan masuknya benda asing ke dalam suatu lingkungan wilayah perairan dan menurunkan kualitas air di wilayah perairan tersebut. Limbah cair domestik merupakan limbah cair yang dihasilkan dari berbagai proses pada kegiatan rumah tangga. Limbah cair domestik tersebut tidak akan mengganggu lingkungan apabila dalam jumlah yang sedikit. Akan tetapi, bila terakumulasi dan menjadi satu, limbah ini dapat menjadi suatu masalah bagi kehidupan organisme lainnya, contohnya kelestarian ekosistem sungai yang ada di daerah perkotaan maupun pedesaan (Pandu, 2017). Penelitian ini bertujuan untuk menganalisis implementasi kebijakan pengendalian pembuangan limbah cair domestik ke badan air penerima di Kabupaten Purwakarta.

\section{METODE}

Metode penelitian yang digunakan pada penelitian ini adalah dengan pendekatan kualitatif non eksperimen yang bersifat studi kasus. Pencarian informan dalam penelitian ini menggunakan menggunakan purposive sampling yang dianggap benar-benar menguasai permasalahan yang akan dianalisis yang berasal dari unsur Dinas Lingkungan Hidup, kelurahan terkait dan masyarakat di sekitar bantaran sungai Cimunjul. Pengumpulan data dalam penelitian ini menggunakan teknik wawancara mendalam, studi dukomen, observasi, dan FGD (Focus Group Discussion). Sedangkan teknik analisis data dalam penelitian ini menggunakan metode Miles dan Huberman (Miles, 1984, pp. 21-23) dengan langkah-langkah sebagai berikut: 1) Mengumpulkan data; 2) Reduksi data; 3) Penyajian data; 4) Penarikan kesimpulan/verifikasi.

\section{HASIL DAN PEMBAHASAN}

Dinas Lingkungan Hidup Kabupaten Purwakarta selama ini telah melakukan pemantauan terhadap kualitas air sungai. Hal ini terbukti dengan adanya kegiatan pemantauan ke beberapa anak sungai yang ada di Kabupaten Purwakarta yang dilaksanakan oleh UPTD Laboratorium Lingkungan untuk pengambilan sampel air sungai dan air limbah yang dihasilkan oleh usaha/kegiatan untuk selanjutnya dianalisa di laboratorium. Implementasi kebijakan merupakan kegiatan yang kompleks dengan berbagai macam faktor yang dapat mempengaruhinya. Analisis implementasi kebijakan pengendalian pembuangan limbah cair domestik ke badan air penerima di Kabupaten Purwakarta dilakukan dengan pendekatan model Edward III. George C. Edward III mengatakan bahwa di dalam pendekatan studi implementasi kebijakan berawal dari bagaimana prakondisi untuk suksesnya kebijakan publik dan apa hambatan utama dari kesuksesan kebijakan publik. Edward III (1980:10) menawarkan empat faktor dalam mengimplementasikan kebijakan publik, yaitu:

\section{a) Komunikasi;}

Implementasi kebijakan pengendalian pembuangan limbah cair domestik ke badan air penerima di Kabupaten Purwakarta akan berjalan secara efektif, apabila yang bertanggung jawab terhadap implementasi sebuah kebijakan mengetahui apa yang harus dilakukannya. Dalam mengimplementasikan kebijakan, perintah harus disampaikan secara jelas, konsisten, dan akurat kepada orang-orang yang cakap dan mampu. 
b) Sumberdaya

Faktor sumber daya mempunyai peranan penting dalam keberhasilan implementasi kebijakan pengendalian pembuangan limbah cair domestik. Faktor sumber daya juga bisa menjadi faktor penghambat dalam keberhasilan implementasi karena dengan keterbatasan jumlah Sumber Daya Manusia yang kompeten dan dukungan anggaran yang memadai, implementasi kebijakan tidak akan terlaksana dengan baik.

c) Disposisi

Pelaksanaan kebijakan dapat dipengaruhi oleh intensitas disposisi para implementor. Keterbatasan intensitas disposisi, dapat menyebabkan gagalnya implementasi kebijakan. Untuk melihat disposisi atau kecenderungan yang ada dapat diamati melalui dampak-dampak dari kecenderungan tersebut, pengangkatan birokrat dan insentif yang diberikan pada organisasi.

d) Struktur birokrasi

Perlu membuat Standard Operational Procedure (SOP) terkait implementasi kebijakan. Pembuatan SOP bertujuan untuk memastikan instruksi kerja tahapan pelaksanaan kebijakan pengendalian pembuangan limbah cair domestik ke badan dir penerima dapat dilaksanakan dengan baik dan benar sesuai prosedur. Fragmentsi telah dilakukan dengan melibat pihak external bidang apabila kasus yang dihadapi melebihi kapasitas dan tupoksi bidang P2KL dan akan dilimpahkan ke bidang lain sesuai dengan tupoksinya masing-masing.

Beberapa sungai yang ada di Purwakarta merupakan anak Sungai Citarum, sekitar 70\% sumber pencemar di Sungai Citarum berasal dari limbah cair domestik. Maraknya program Citarum Harum yang menargetkan air Sungai Citarum dapat diminum setelah 7 (tujuh) tahun kedepan, tentunya tidak akan tercapai apabila anak-anak Sungai Citarum tetap dibiarkan tercemar. Untuk mendukung keberhasilan program ini, perlu adanya pengawasan dan pengendalian pencemaran air sungai oleh limbah cair domestik. Dalam menanggulangi pencemaran air sungai oleh limbah domestik, maka dikeluarkan PerMenLHK RI No. P.68/ Menlhk/ Setjen/ Kum.1/ 8/ 2016 tentang Baku Mutu Air Limbah Domestik. Sumber pencemar yang berasal dari limbah cair domestik memberikan kontribusi terbesar terhadap pencemaran air sungai, seperti yang telah digambarkan dalam tabel I.3 untuk parameter BOD. Salah satu faktor penyebabnya adalah masih ada beberapa masyarakat yang bermukim dibantaran sungai. Dalam penelitian ini, peneliti akan menganalisis jumlah pencemar yang dibuang ke Sungai Cimunjul yang berasal dari limbah cair domestik. Berdasarkan informasi yang diperoleh dari kelurahan, masih terdapat sejumlah penduduk yang tinggal di bantaran Sungai Cimunjul termasuk dalam wilayah Kelurahan Nagri Kidul dan Sindangkasih. Sejauh ini mereka masih membuang limbah cair domestik ke sungai secara langsung tanpa melalui pengolahan terlebih dahulu. Sejauh ini, Dinas Lingkungan Hidup Kabupaten Purwakarta belum bisa melaksankan pengendalian pencemaran air sungai oleh limbah cair domestik karena belum ada aturan teknis terkait pengendalian pencemaran oleh limbah cair domestik tersebut.

Tabel 2. Jumlah Penduduk yang Bermukim di Bantaran Sungai Cimunjul

\begin{tabular}{|c|c|c|c|}
\hline No. & Kelurahan/RW & Jumlah KK & Jumlah Penduduk (Orang) \\
\hline & Nagri Kidul & & \\
\hline 1. & RW 03 & 151 & 3.204 \\
\hline 2. & RW 05 & 1.169 & 1.862 \\
\hline 3. & RW 06 & 503 & 1.084 \\
\hline
\end{tabular}


Kebijakan: Jurnal Ilmu Administrasi

Volume 12, Nomor 1, Januari 2021

E-ISSN: 2656-2820

P-ISSN 1829-5762

\begin{tabular}{|c|c|c|c|}
\hline No. & Kelurahan/RW & Jumlah KK & Jumlah Penduduk (Orang) \\
\hline 4. & RW 08 & 604 & 1.358 \\
\hline & Sindangkasih & & \\
\hline 5. & RW 01 & 305 & 1.261 \\
\hline 6. & RW 02 & 320 & 1.932 \\
\hline 7. & RW 03 & 319 & 2.090 \\
\hline 8. & RW 05 & 218 & 900 \\
\hline 9. & RW 07 & 310 & 1.059 \\
\hline 10. & RW 13 & 347 & 1.391 \\
\hline & & Jumlah Total & 16.141 \\
\hline
\end{tabular}

Sumber: Kelurahan Nagrikidul dan Sindangkasih, 2020

Berdasarkan Tabel 2 dapat diketahui jumlah penduduk yang bermukim di bantaran Sungai Cimunjul berjumlah 16.141 orang. Hasil kegiatan limbah domestik setiap orang apabila diasumsikan akan menghasilkan limbah cair sekitar 100 Liter/orang/hari. Apabila jumlah penduduk yang membuang limbah cair domestik ke sungai sebanyak 16.141 orang, maka jumlah limbah cair domestik yang akan dihasilkan adalah sekitar 1.614.100 Liter/hari tanpa melalui proses pengolahan terlebih dahulu. Tentunya hal ini akan menjadi masalah besar apabila tidak dikendalikan dan dikelola dengan baik, karena jumlah pencemar akan terakumulasi dari waktu ke waktu. Sedangkan baku mutu yang diperbolehkan untuk membuang air limbah domestik setelah melalui proses pengolahan pada IPALD ditetapkan melalui PerMenLHK RI No. P.68/ Menlhk/ Setjen/ Kum.1/ 8/ 2016.

Tabel 3. Status Mutu Air Anak Sungai Citarum di Purwakarta Tahun 2014 - 2017

\begin{tabular}{|c|c|c|c|c|c|c|c|}
\hline No. & Nama Anak & Waktu Sampling & Lokasi & \multicolumn{4}{|c|}{ Indeks Pencemaran (Tahun) } \\
\cline { 5 - 8 } & Sungai & (Semester) & Sampling & $\mathbf{2 0 1 4}$ & $\mathbf{2 0 1 5}$ & $\mathbf{2 0 1 6}$ & $\mathbf{2 0 1 7}$ \\
\hline 1 & Cikao & I & Hulu & C & B & C & C \\
\hline & & & Hilir & C & B & C & C \\
\hline & & II & Hulu & C & B & B & C \\
\hline & & & Hilir & C & B & C & C \\
\hline 2 & Cikembang & I & Hulu & C & C & B & A \\
\hline & & & Hilir & C & B & B & B \\
\hline & & II & Hulu & C & B & B & B \\
\hline & & & Hilir & C & B & B & B \\
\hline 3 & Cikuda & I & Hulu & C & C & B & B \\
\hline & & & Hilir & C & B & B & B \\
\hline & & II & Hulu & C & B & B & C \\
\hline & & & Hilir & B & B & B & C \\
\hline 4 & Cigalugur & I & Hulu & C & C & C & B \\
\hline & & & Hilir & B & C & B & B \\
\hline & & II & Hulu & C & C & C & C \\
\hline & & & Hilir & C & C & C & C \\
\hline 5 & Cimunjul & I & Hulu & C & C & B & A \\
\hline & & & Hilir & C & B & B & B \\
\hline & & II & Hulu & C & C & B & C \\
\hline & & & Hilir & C & C & C & C \\
\hline
\end{tabular}


Keterangan:

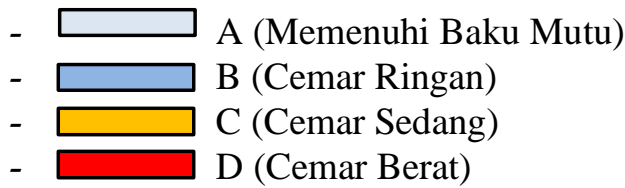

Sumber: DLH Kabupaten Purwakarta, 2018

Pada tabel 3 dapat diketahui bahwa nilai indeks pencemaran dari kelima sungai tersebut berubahubah (fluktuatif) setiap tahunnya. Kondisi air sungai di Purwakarta mengalami pencemaran dengan kategori cemar ringan sampai sedang. Hal ini menunjukkan bahwa masih perlu upaya peningkatan pengendalian pembuangan air limbah ke sumber air dengan memperhatikan semua faktor yang mempenggaruhi pencemaran air sungai. Sejauh ini, hanya air limbah industri yang diatur pengelolaannya, yaitu melalui Peraturan Bupati Purwakarta No. 179 Tahun 2017 tentang Izin Pembuangan Limbah Cair ke Sumber Air atau Badan Air. Sedangkan untuk teknis pengelolaan air limbah domestik belum diatur oleh pemerintah Kabupaten Purwakarta, sementara air limbah domestik termasuk salah satu penyumbang pencemaran air sungai. Berdasarkan uraian di atas, dapat diketahui bahwa implementasi kebijakan pengendalian pembuangan air limbah domestik belum dapat dilaksanakan karena belum ada aturan yang mengatur terkait pengelolaan limbah cair domestik pada tingkat operasional sebagai penjabaran dari PermenLHK No. P.68 tahun 2016. Oleh sebab itu pihak Dinas Lingkugan Hidup belum bisa melakukan pemantauan dan pengawasan terkait pengendalian pembuangan air limbah domestik ke badan air penerima/sungai di Kabupaten Purwakarta.

\section{SIMPULAN}

Berdasarkan hasil penelitian tentang analisis implementasi kebijakan pengendalian pembuangan limbah cair domestik di Kabupaten Purwakarta disimpulkan bahwa implementasi kebijakan pengendalian pembuangan limbah cair domestik di Kabupaten Purwakarta belum terlaksana karena belum ada pengaturan terkait pengelolaan air limbah domestik tersebut. Sejauh ini air limbah domestik langsung dibuang ke saluran drainase/got dan sungai/kali karena belum tersedianya sarana dan prasarana pengelolaan air limbah domestik, kurangnya pemahaman masyarakat terhadap dampak air limbah domestik terhadap pencemaran air. Di samping itu belum adanya aturan tingkat operasional terkait implementasi kebijakan pengelolaan air limbah domestik yang mengacu pada PerMen LHK RI Nomor P.68/Menlhk/Setjen/Kum.1/8/2016 tentang baku mutu air limbah domestik.

Langkah-langkah yang dapat dilakukan adalah dengan mengoptimalkan kinerja sumberdaya manusia yang terbatas, penyediaan anggaran, dan kerjasama antara pihak pemerintah, swasta dan masyarakat. Implementasi kebijakan akan terlaksana dengan baik apabila Kabupaten Purwakarta telah mempunyai acuan diantaranya data inventarisasi dan identifikasi sumber pencemar limbah cair domestik, Standard Operational Procedure (SOP) Pengendalian Pembuangan Limbah Cair Domestik, dan peraturan bupati tentang pengelolaan limbah cair domestik.

\section{DAFTAR PUSTAKA}

Agustino, L. (2017). Dasar Dasar Kebijakan Publik. Alfabeta.

Edwar III, G. C. (1980). Implementing Public Policy. Congressional Quarterly Press.

Miles, Matthew, B., Huberman, Michae. A. 1984. Qualitative Data. London: SAGE Publications.

Nugroho, R. D. (2008). Kebijakan Publik: Formulasi, Implementasi, dan Evaluasi. Elex Media Komputindo. 
Kebijakan: Jurnal Ilmu Administrasi

Volume 12, Nomor 1, Januari 2021

E-ISSN: 2656-2820

P-ISSN 1829-5762

Pandu, K. (2017). Pengertian Limbah Domestik, Contoh, Gambar, dan Penjelasannya. http://www.ebiologi.net/2017/01/pengertian-limbah-domestik.html

Subarsono, A. G. (2011). Kebijakan Publik: Konsep, Teori, dan Aplikasi. Pustaka Pelajar.

Subarsono, A. G. (2015). Analisis Kebijakan Publik: Konsep, Teori, dan Aplikasi. Pustaka Pelajar.

Teguh, I. (2019). Sejarah Pengelolaan Sungai Citarum \& Semrawutnya Program Pemerintah. https://tirto.id/sejarah-pengelolaan-sungai-citarum-semrawutnya-program-pemerintah-dhnt,

Winarno, B. (2016). Kebijakan Publik Era Globalisasi: Teori, Proses, dan Studi Kasus Komparatif. CAPS (Centre of Academic Publishing Service).

\section{Peraturan Perudangan}

Peraturan Menteri Lingkungan Hidup dan Kehutanan RI Nomor P.68/ Menlhk/ Setjen/ Kum.1/ 8/ 2016 tentang Baku Mutu Air Limbah Domestik. 